\title{
TATA LAKSANA PEMERIKSAAN NEUROLOGIS VIRTUAL DI ERA PANDEMI CORONA VIRUS DISEASE 2019
}

\author{
Ni Made Susilawathi ${ }^{1}$, Kumara Tini ${ }^{1}$, Ida Ayu Sri Wijayanti ${ }^{1}$, Putu Lohita Rahmawati ${ }^{1}$, Putu Gede Sudira ${ }^{2}$, Dewa \\ Putu Wisnu Wardhana ${ }^{3}$, Dewa Putu Gde Purwa Samatra ${ }^{1}$ \\ ${ }^{1}$ Departemen Neurologi, FK Universitas Udayana/RS Universitas Udayana, Bali, Indonesia \\ ${ }^{2}$ Departemen Pendidikan Kedokteran dan Kesehatan, FK Universitas Udayana, Bali, Indonesia \\ ${ }^{3}$ Departemen Bedah Saraf, FK Universitas Udayana/RS Universitas Udayana, Bali, Indonesia
}

Diterima 9 Juli 2020

Disetujui 24 Agustus 2020

Publikasi 25 November 2020

Korespondensi: susilawathi@unud.ac.id
Cara merujuk artikel ini: Susilawathi (et al). 2020. Tata Laksana Pemeriksaan Neurologis Virtual di Era Pandemi Corona Virus Disease 2019. Callosum Neurology Journal 3(3): 102-112.

DOI: https://doi.org/10.29342/cnj.v3i3.119

\section{ABSTRAK}

Latar Belakang: Pandemi Corona Virus Disease 2019 (COVID-19) dengan penularannya yang sangat cepat di seluruh dunia berdampak terhadap perubahan pelayanan kesehatan di bidang neurologi sebagai upaya mendukung program pengendalian penyakit ini.

Tujuan: Merumuskan rekomendasi panduan pemeriksaan neurologis untuk pelayanan teleneurologi.

Diskusi: Penyesuaian dalam pelaksanaan pelayanan neurologi perlu segera dilakukan dengan mengadopsi metode pelayanan dengan telemedicine terutama dalam tata cara pemeriksaan pasien dengan pembatasan fisik dan sosial sebagai salah satu langkah pencegahan infeksi SARS-CoV-2.

Kesimpulan: Layanan teleneurologi perlu dikembangkan dalam pelayanan neurologi termasuk pengembangan prosedur pemeriksaan neurologis secara virtual.

Kata kunci: COVID-19, Pemeriksaan neurologi, Pemeriksaan virtual, Pembatasan fisik

\section{ABSTRACT}

Background: Rapid transmission of Corona Virus Disease 2019 (COVID-19) has changed health care delivery procedures to prevent the spreading of the disease and protect healthare professionals.

Purpose: To provide recommendation of neurological examination guideline for teleneurology services during COVID-19 pandemic.

Discussion: Adaptation of telemedicine in neurology services has to be performed immediately to prevent the SARS-CoV-2

infection. Several procedures of neurological examination can be performed virtually and still reliable to guide neurologist in formulating clinical assessment and judgement.

Conclusion: Teleneurology services and virtual neurological examination has to be developed during COVID-19 pandemic.

Keywords: COVID-19, Neurological examination, Virtual examination, Physical restriction 


\section{Latar Belakang}

Pandemi Corona Virus Diseases 2019 (COVID-19) menimbulkan perubahan besar pada tatanan kehidupan masyarakat, termasuk hubungan antara dokter dan pasien. Perubahan tersebut mencakup peningkatan upaya pencegahan dan pengendalian infeksi berupa penggunaan alat pelindung diri, kaidah mencuci tangan, serta pembatasan fisik maupun sosial. ${ }^{1,2}$ Peningkatan jumlah pasien terinfeksi COVID-19 secara drastis sejak akhir tahun 2019 menyebabkan beban besar pada sistem dan ketidaksiapan pelayanan di fasilitas kesehatan. $^{3}$ Kombinasi dari peningkatan jumlah kasus yang menyebabkan kelebihan kapasitas pelayanan di Unit Gawat Darurat, keterbatasan alat pelindung diri berujung pada banyaknya tenaga kesehatan yang terinfeksi bahkan meninggal dunia., ${ }^{4,5}$ Mengantisipasi hal tersebut, perlu adanya pembatasan fisik dan sosial dalam prosedur pelayanan neurologi dengan pengembangan layanan kesehatan secara virtual (teleneurologi) termasuk pemeriksaan neurologi. 5,6 Tantangan terbesar seorang dokter adalah mendiagnosis pasiennya. Diagnosis neurologi merupakan proses sintesis deduktif berdasarkan data ananmnesis, pemeriksaan fisik, dan pemeriksaan penunjang (seperti pemeriksaan laboratorium dan imajing pasien).,8 Diagnosis neurologi sangat berkaitan dengan diagnosis topik suatu kelainan neurologis (klinis). ${ }^{9} \quad$ Prosedur pemeriksaan klinis neurologi yang baik merupakan aplikasi langsung berdasarkan ilmu dasar neurologi (neuroscience), dan dapat diterapkan guna memeriksa individu dengan kondisi sehat maupun sakit. ${ }^{7}$ Perkembangan pesat teknologi kedokteran memunculkan berbagai pemeriksaan baru yang lebih fokus dan praktis. Beberapa prosedur pemeriksaan klinis telah tidak dipergunakan lagi karena minimnya korelasi klinis. Sebagian prosedur pemeriksaan telah digantikan dengan teknologi diagnostik yang baru ${ }^{8}$, salah satu contohnya berupa upaya menerapkan teleneurologi (telemedicine) utamanya di masa pandemi ini. 5,6 Berbagai keuntungan dapat diperoleh bagi klinisi yang mampu menyediakan layanan virtual teleneurologi bagi pasiennya. Penggunaan platform telemedicine pada pelayanan kesehatan termasuk teleneurologi dapat meningkatkan akses antara dokter dan pasien. ${ }^{10,11}$ Aplikasi teleneurologi dalam praktik klinis dirasa efektif, meskipun pemeriksaan fisik secara langsung masih merupakan metode terbaik guna mendiagnosis suatu penyakit. ${ }^{6,12}$ Metode pemeriksaan virtual di era pandemi COVID-19 sangat diperlukan terutama oleh para dokter garis terdepan guna mengurangi beban kerja, mengoptimalkan waktu perawatan pasien dan, mengurangi risiko paparan infeksi. ${ }^{4,6,13}$ Tinjauan pustaka ini merekomendasikan prosedur pemeriksaan neurologi virtual tanpa mengurangi nilainya sebagai prosedur penapisan untuk mengidentifikasi permasalahan neurologis pada masa pandemi.

\section{Prinsip Pemeriksaan Neurologi}

Pemeriksaan neurologi terdiri atas pemeriksaan status mental, saraf kranialis, motorik, sensorik, refleks, fungsi serebelum, koordinasi, gaya jalan, dan tanda lainnya. Pendekatan pemeriksaan neurologi secara umum dapat dilakukan dengan dua cara, yaitu secara regional (penilaian sesuai area tertentu) dan secara sistem (misalnya penilaian terhadap sistem motorik, dsb). Klinisi sering menggunakan kedua pendekatan tersebut secara simultan atas dasar pertimbangan efektif dan efisien. ${ }^{8}$

\section{Pemeriksaan Neurologi Virtual (PNV)}

Telekonsultasi klinis merupakan bagian dari pelayanan telemedicine yang memberikan pelayanan konsultasi jarak jauh guna membantu penegakan diagnosis dan/ atau memberikan pertimbangan/ saran tata laksana medis pasien. Dokter memberikan pelayanan melalui media tulis, suara, dan/ atau video yang harus terdokumentasi (direkam dan dicatat) di rekam medis sesuai ketentuan yang berlaku. ${ }^{15}$ Telekonsultasi di era pandemik COVID-19 menjadi semakin populer karena tidak saja berupa konsultasi langsung dokter dengan pasien, juga konsultasi antar dokter. ${ }^{16}$ Teleneurologi merupakan layanan telemedicine di bidang neurologi yang dikembangkan sebagai solusi bagi masalah keterbatasan akses ke fasilitas layanan neurologi, baik berupa lokasi yang terpencil, waktu tempuh yang lama, dan disabilitas pasien. ${ }^{17}$

Teleneurologi membutuhkan prosedur pemeriksaan pasien secara virtual. Pemeriksaan neurologis virtual (PNV) dapat membantu klinisi untuk memeriksa kondisi klinis pasien melalui kunjungan virtual selama pandemi COVID-19. Prosedur ini juga dapat menjadi standar baru pemeriksaan neurologi di masa mendatang. Tantangan pelaksanaan PNV berupa proses adaptasi pemeriksaan fisik konvensional menjadi pemeriksaan virtual. Keterbatasan PNV adalah tidak semua pemeriksaan neurologi dapat dilakukan secara virtual, seperti pemeriksaan 
kekuatan otot pada konsultasi neuromuskular, konsultasi sakit kepala dan manuver vertigo. Pemeriksaan ini tidak sepenuhnya dapat menggantikan pemeriksaan fisik neurologi secara langsung. ${ }^{6}$
Panduan berikut dapat membantu dokter spesialis neurologi guna memilih pemeriksaan neurologi yang dapat dilakukan virtual sebagai implementasi layanan teleneurologi.

Tabel 1. Pemeriksaan Penapisan Neurologis ${ }^{8}$

1. Penilaian kondisi mental pasien selama wawancara/ komunikasi dengan dokter.

2. Pemeriksaan saraf kranialis II, III, IV, VI; termasuk pemeriksaan tajam penglihatan, lapang pandang, refleks pupil, gerak ekstraokular, dan funduskopi.

3. Pemeriksaan saraf kranialis VII, VIII, IX, X, XII; termasuk pemeriksaan otot wajah, ekspresi wajah, fungsi pendengaran, cara berbicara, dan pemeriksaan lidah.

4. Pemeriksaan motorik keempat ekstremitas; berupa kekuatan otot, tonus, dan tropik pada daerah proksimal dan distal.

5. Pemeriksaan sensorik; meliputi penilaian sensasi nyeri dan suhu di medial dan lateral keempat ekstremitas, juga penilaian vibrasi dan rabaan di pergelangan kaki.

6. Pemeriksaan koordinasi; berupa prosedur diadokokinesis, tes jari-hidung, dan penilaian gaya jalan.

7. Pemeriksaan klonus dan penilaian refleks fisiologis (biseps, triseps, brakhioradialis, quadrisep, achiles, dan plantar).

Apabila pada penapisan di atas menunjukkan abnormalitas atau gejala spesifik, maka pemeriksaan harus dilanjutkan dengan lebih lengkap dan spesifik.

Pemeriksaan neurologi harus dilakukan secara terencana. Idealnya, pemeriksaan penapisan neurologi dilakukan terlebih dahulu (tabel 1) sebagai dasar merumuskan pemeriksaan lanjutan yang dibutuhkan. Pemeriksaan tidak harus dikerjakan dengan urutan tertentu, namun disesuaikan dengan kondisi klinis pasien. ${ }^{8}$ Pemeriksa harus memberikan instruksi yang sederhana, singkat, dan mudah dipahami oleh pasien dan/atau pendamping pasien. Saat memberikan instruksi prosedur pemeriksaan yang kompleks, akan lebih baik bila pemeriksa dan/atau asisten pemeriksa memberikan demonstrasi kepada pasien dibandingkan hanya memberikan instruksi kalimat yang panjang dan menyebabkan pasien salah menginterpretasinya. ${ }^{9}$

\section{Tata Laksana Umum}

Pemeriksaan Neurologi Virtual dikerjakan sesuai panduan yang telah ditetapkan dan kondisi yang ideal. Pasien berada dalam posisi duduk di ruangan yang terang dan tanpa penghalang visual antara pasien dan kamera. Ruangan cukup lapang dan tenang sehingga pasien dapat bergerak leluasa menuju atau menjauhi kamera. Ruang yang luas juga memudahkan pengamatan gaya jalan pasien. ${ }^{6}$ Adanya pendamping pasien terutama dari keluarga terdekat akan sangat memudahkan melakukan PNV karena dapat membantu membimbing pasien memahami instruksi, mengatur kamera, dan mengontrol kondisi ruangan., 5 Pemilihan platform online yang aman sangat penting guna menjamin kelancaran pemeriksaan dan menjaga kerahasiaan pasien. ${ }^{5,18}$ Jaringan internet dengan koneksi yang memadai serta bandwidth yang tinggi (> $100 \mathrm{kbs}$ ) s) diperlukan untuk kelancaran konsultasi. ${ }^{5}$

\section{Persiapan Pemeriksaan Neurologi Virtual}

Pelaksanaan PNV memerlukan persiapan yang matang agar layanan virtual dapat berjalan dengan baik (Tabel 2). Fasilitas pelayanan kesehatan, mewakili dokter akan menginformasikan terlebih dahulu jadwal pelaksanaan, instruksi mengenai prosedur persiapan pemeriksaan, alat dan bahan yang dibutuhkan saat pemeriksaan, formulir terkait pemeriksaan yang akan dilakukan, biaya dan cara pembayaran layanan, serta platform telekomunikasi yang akan digunakan untuk PNV kepada pasien dan/atau keluarga.,19 Dokter, pasien, dan/atau pendamping pasien selanjutnya memastikan alat telekomunikasi yang digunakan terkoneksi dengan jaringan internet yang stabil 
dan telah terisi baterai cukup. Posisi alat komunikasi diatur agar kamera menampilkan gambar pasien dengan optimal serta audio dan mikrofon dipastikan bekerja. Dokter pemeriksa mempersiapkan alat tulis dan form PNV untuk mendokumentasikan hasil pemeriksaan. ${ }^{5,19}$

Sesi permulaan sangat penting dibangun di awal. Penjelasan tentang layanan teleneurologi kepada pasien dan/atau pendamping pasien dilakukan sebelum PNV dengan mengisi informed consent dan didokumentasikan dengan baik. ${ }^{12,19}$ Dokter pemeriksa wajib memperkenalkan diri dan mengucapkan salam pembuka. Dokter harus memastikan bahwa individu yang diperiksa adalah benar pasien yang bersangkutan sesuai dengan prinsip keselamatan pasien. , $^{5,19}$

Tabel 2. Persiapan Pemeriksaan Neurologi Virtual

\section{Pembukaan}

- Persiapkan diri dengan penampilan yang menarik, perkenalkan diri, dan ucapkan salam sapa.

- Pastikan pasien dan pendampingnya hadir tepat waktu.

- Pastikan kondisi ruangan memadai (pencahayaan cukup, tidak bising, dan latar belakang polos).

- Periksa kembali identitas pasien dengan meminta pasien menyebutkan nama dan tanggal lahir.

- Berikan empati kepada pasien secara virtual dan gunakan pilihan kata yang cermat, misalnya:

- Kalimat pembuka, "Terimakasih telah mengundang saya di rumah anda."

- Tunjukan keseriusan menyimak pasien, "Saya menangkap kekhawatiran di suara anda."

- Setelah pasien menjelaskan suatu masalah, "Mohon ceritakan lebih rinci tentang...."

- Jika pasien merasa khawatir dengan penggunaan media virtual, "Saya menyadari bahwa metode kunjungan ini masih baru, namun terima kasih telah mencobanya."

- Informasikan kepada pasien bahwa selama wawancara dokter akan sekaligus mengetik data yang diperoleh, "Saya akan mengetik saat kita bicara untuk menyimpulkan cerita anda dengan baik."

\section{Formulir Persetujuan Teleneurologi}

Pelayanan teleneurologi memerlukan persetujuan dari pasien atau keluarganya sesuai ketentuan dari tempat praktek/ institusi dokter pemeriksa. Formulir persetujuan mencakup tentang:

- Identitas pasien dan alamat situs.

- Identitas dokter, alamat situs, dan SIP (Surat Ijin Praktek).

- Persetujuan lisan pasien untuk berpartisipasi dalam pelayanan teleneurologi.

- Kondisi yang mendasari pelayanan teleneurologi, misalnya berlangsungnya pandemi COVID-19 sebagai kedaruratan kesehatan masyarakat.

- Dokter telah menginformasikan dan mendiskusikan tentang layanan teleneurologi berupa: - penilaian pasien dilakukan secara tidak secara langsung (virtual), pemberian rekomendasi diagnosis, serta tata laksana sesuai dengan keahlian dokter,

- kemungkinan adanya gangguan teknis layanan virtual,

- pelayanan yang dilakukan disimpan dalam rekam medik yang dijaga kerahasiaanya dan tidak ada perekaman lain,

- tim medis akan memberikan perawatan tindak lanjut secara langsung apabila diperlukan.

- Perlu ada saksi dari keluarga.

\section{Pemeriksaan Fisik Umum}

- Keadaan umum melalui inspeksi melalui panggilan video.

- Penilaian tanda vital, bila tersedia dapat menggunakan peralatan medis di rumah pasien.

Penilaian Status Mental dan Fungsi Luhur secara Virtual

Pemeriksaan status mental dimulai dengan pemeriksaan tingkat kesadaran pasien dan pemeriksaan kognitif dasar Mini-Mental State Examination (MMSE) guna mengevaluasi orientasi (terhadap waktu, tempat, dan orang), atensi, memori (jangka pendek dan jangka panjang), kemampuan berhitung, kemampuan berbahasa, kemampuan praksis (melakukan tugas sederhana) dan meniru satu set pentagon yang berpotongan. $^{7,9}$ Pemeriksaan tambahan dapat berupa instruksi menggambar jam (Clock Drawing Test) untuk menilai fungsi luhur spesifik. ${ }^{7}$ 


\section{Pemeriksaan Saraf Kranialis secara Virtual}

Pemeriksaan saraf kranialis I-XII tidak bisa diperiksa dalam urutan yang kaku. Beberapa saraf berkontribusi terhadap satu fungsi neurologis tertentu, misalnya pada fungsi pergerakan bola mata. ${ }^{9}$ Pemeriksaan saraf kranialis tidak bisa dikerjakan dengan lengkap pada PNV. Pemeriksaan pupil, refleks pupil, refleks kornea dan funduskopi sangat sulit dikerjakan. ${ }^{20}$ Pemeriksaan funduskopi jarak jauh dengan teknologi baru yang dipadukan pada aplikasi smartphone mulai dikembangkan, ${ }^{21}$ namun saat ini tidak semua fasilitas pelayanan mampu melakukan pemeriksaan tersebut.

Pemeriksaan visus dan lapang pandang didahului dengan pemeriksaan subjektif berdasarkan keluhan pasien. Dokter akan mengonfirmasi gangguan visus yang telah dialami atau adanya keluhan gangguan lapang pandang pasien. Pemeriksaan visus dapat dilakukan dengan pemeriksaan hitung jari dengan bantuan pendamping pasien. Pemeriksaan lapang pandang dapat dilakukan dengan menanyakan pada pasien apakah ada wajah pemeriksa yang tidak terlihat. ${ }^{6,20}$
Apabila pemeriksaan visus dan lapang pandang diperlukan secara mendetail, pemeriksa dapat memanfaatkan Eye Handbook App yang dapat diunduh pada smartphone. Aplikasi tersebut dilengkapi dengan near vision card, Amsler Gird dan color vision test. ${ }^{20}$

Pemeriksaan pupil dan kedudukan serta pergerakan bola mata masih mungkin dilakukan dengan meminta pasien memposisikan matanya dekat ke kamera. Apabila sangat diperlukan, guna meningkatkan ketelitian pemeriksaan, pemeriksa dapat memanfaatkan fitur screenshot atau screen recording dari alat komunikasi, sehingga dapat mengevaluasi kembali setelah PNV selesai dilaksanakan. Proses tambahan perekaman selama sesi harus disampaikan di awal pemeriksaan dan telah disetujui oleh pasien atau keluarganya ${ }^{20}$

Pemeriksaan fungsi saraf kranialis lain dilakukan dengan prinsip serupa. Prosedur pemeriksaan dapat dilihat di tabel 3. Dokter akan memberi instruksi kepada pasien, kemudian pasien mengerjakan instruksi tersebut dan dapat dibantu oleh pendamping pasien. ${ }^{20}$

Tabel 3. Formulir Pemeriksaan Neurologi Virtual

\begin{tabular}{|c|c|c|}
\hline Pemeriksaan & Prosedur & Interpretasi \\
\hline 1. Kesadaran & Pemeriksaan Glasgow Coma Scale (GCS) & $\mathrm{E} \ldots \mathrm{V} \ldots \mathrm{M} \ldots$ \\
\hline $\begin{array}{l}\text { 2. Status } \\
\text { Mental }\end{array}$ & Formulir Mini Mental State Examination & $\begin{array}{l}\text { Gangguan kognitif } \\
\text { Skor 24-30: normal } \\
\text { Skor 17-23: } \\
\text { probable } \\
\text { Skor 0-16: definite }\end{array}$ \\
\hline $\begin{array}{l}\text { 3. Fungsi } \\
\text { Luhur }\end{array}$ & Clock Drawing Test, Line Bisection Test, Cancelation Test & $\begin{array}{l}\text { pemeriksaan } \\
\text { lanjutan } \\
\text { diperlukan }\end{array}$ \\
\hline \multicolumn{3}{|c|}{ 4. Saraf kranialis } \\
\hline N. I & $\begin{array}{l}\text { Pemeriksaan subyektif berdasarkan keluhan: } \\
\text { - Keluhan telinga hidung tenggorok disingkirkan } \\
\text { - Gangguan penghidu } \\
\text { - } \quad \text { Gangguan perasa }\end{array}$ & $\begin{array}{l}\text { Kemungkinan } \\
\text { hiposmia/ anosmia }\end{array}$ \\
\hline N. II & $\begin{array}{l}\text { Pemeriksaan subyektif berdasarkan keluhan: } \\
\text { - } \quad \text { Gangguan visus } \\
\text { - Gangguan lapang pandang } \\
\text { Skotoma } \\
\text { Pemeriksaan obyektif: } \\
\text { - Visus dengan hitung jari (bantuan pendamping) } \\
\text { - Lapang pandang (memerhatikan wajah pemeriksa) } \\
\text { Dapat memanfaatkan Eye Handbook App }\end{array}$ & \\
\hline
\end{tabular}


Tabel 3. Formulir Pemeriksaan Neurologi Virtual (Lanjutan)

\begin{tabular}{|c|c|c|}
\hline Pemeriksaan & Prosedur & Interpretasi \\
\hline N. III, IV, VI & 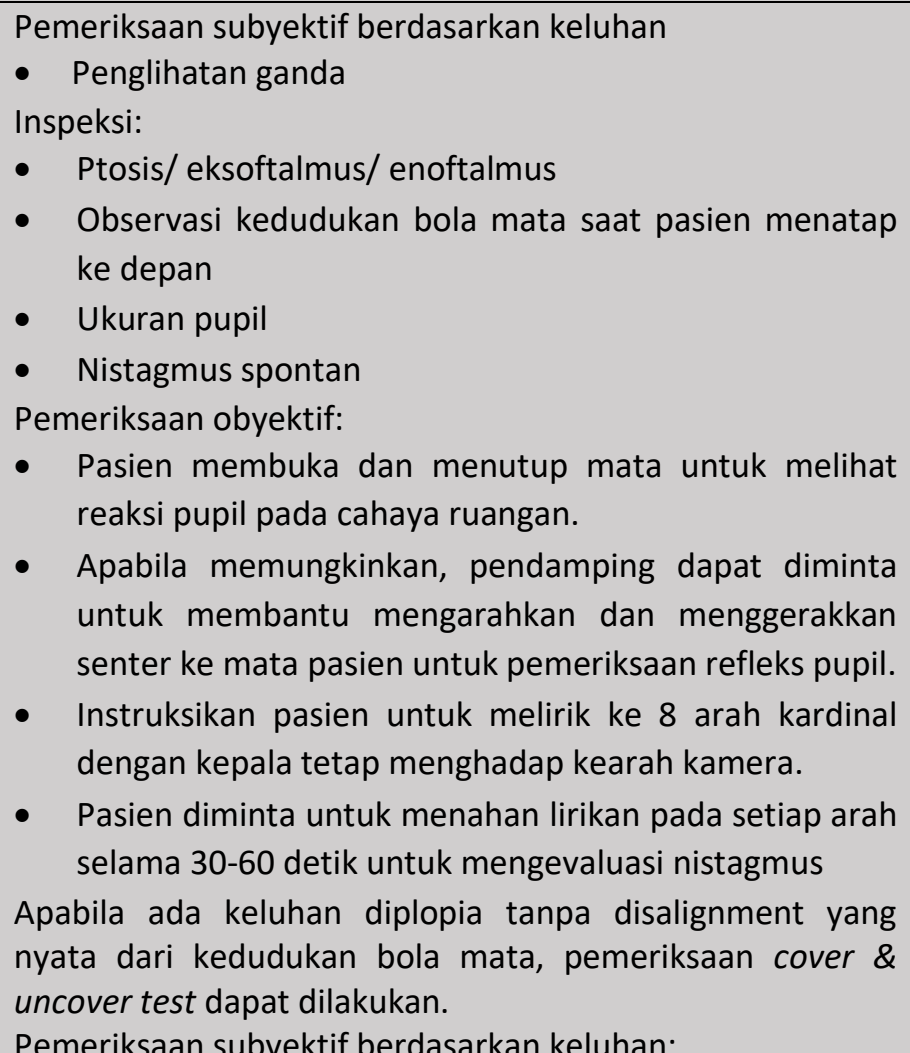 & $\begin{array}{ll}\text { - } & \text { Diplopia } \\
\text { - } & \text { Setangkup/ } \\
\text { strabismus } \\
\text { - } \\
\text { Midriasis/ } \\
\text { miosis/ anisokor }\end{array}$ \\
\hline N. V & $\begin{array}{l}\text { Pemeriksaan subyektif berdasarkan keluhan: } \\
\text { - Keluhan gangguan sensorik pada wajah sesuai } \\
\text { dermatom } \mathrm{V}_{1} / \mathrm{V}_{2} / \mathrm{V}_{3} / \text { parestesi sirkum oral. } \\
\text { Pemeriksaan obyektif: } \\
\text { - Inspeksi untuk mengevaluasi atrofi di area temporalis. } \\
\text { - Instruksikan pasien untuk membuka mulutnya. } \\
\text { Perhatikan adanya deviasi rahang. } \\
\text { Apabila terdapat keluhan sensorik, lakukan pemeriksaan } \\
\text { dengan bantuan pendamping menggunakan kapas, } \\
\text { kantong es/sendok dingin dan tusuk gigi. }\end{array}$ & $\begin{array}{l}\text { Lesi perifer } \\
\text { Lesi sentral }\end{array}$ \\
\hline N. VIII & $\begin{array}{l}\text { Pemeriksaan subyektif berdasarkan keluhan: } \\
\text { - Gangguan pendengaran dan/ atau tinnitus. } \\
\text { Pemeriksaan obyektif: } \\
\text { - Pendamping diminta untuk menggesekkan jari di depan } \\
\text { telinga pasien secara bergantian dan bersamaan } \\
\text { apabila pasien ada keluhan gangguan pendengaran } \\
\text { Keseimbangan dapat diperiksa dengan tes Romberg dan } \\
\text { Fukuda stepping test. }\end{array}$ & Bilateral/ unilateral \\
\hline N. IX, X & $\begin{array}{l}\text { Pemeriksaan subyektif berdasarkan keluhan: } \\
\text { - Keluhan gangguan menelan dan suara serak } \\
\text { Pemeriksaan obyektif: } \\
\text { - Selama proses anamnesis perhatikan apakah terdapat } \\
\text { abnormalitas saat pasien memproduksi suara (sengau, } \\
\text { serak, spastik, disartia). } \\
\text { - Instruksikan pasien untuk menyuarakan "pa", "ta”, "ka" } \\
\text { - Instruksikan pasien untuk menelan dan batuk. }\end{array}$ & $\begin{array}{l}\text { Dysfagia neurogenik } \\
\text { Dysfonia }\end{array}$ \\
\hline
\end{tabular}


Tabel 3. Formulir Pemeriksaan Neurologi Virtual (Lanjutan)

\begin{tabular}{|c|c|c|}
\hline Pemeriksaan & Prosedur & Interpretasi \\
\hline N. XI & $\begin{array}{l}\text { Pemeriksaan obyektif: } \\
\text { - Instruksikan pasien untuk memperlihatkan area leher } \\
\text { dan bahunya. Inspeksi untuk mengevaluasi atrofi pada } \\
\text { otot trapezius dan sternocleidomastoid. } \\
\text { - Instruksikan pasien untuk menoleh ke kiri, menoleh ke } \\
\text { kanan, serta mengangkat bahunya guna mengevaluasi } \\
\text { gerakan otot. }\end{array}$ & Lesi perifer \\
\hline N. XII & $\begin{array}{l}\text { Inspeksi: } \\
\text { - Instruksikan pasien untuk membuka mulutnya dan } \\
\text { evaluasi keadaan lidah saat istirahat. Observasi tremor, } \\
\text { fasikulasi dan atrofi } \\
\text { Pemeriksaan obyektif: } \\
\text { - Instruksikan pasien untuk menjulurkan lidah dan } \\
\text { menggerakkannya ke kiri dan kanan secara cepat. } \\
\text { - Instruksikan pasien untuk mengucapkan "ular lari } \\
\text { lurus" secara cepat. }\end{array}$ & Lesi perifer/ sentral \\
\hline $\begin{array}{l}\text { 5. Motorik } \\
\text { Ekstremitas } \\
\text { superior }\end{array}$ & $\begin{array}{l}\text { - Instruksikan pasien untuk melakukan gerakan melawan } \\
\text { gravitasi berupa abduksi lengan, ekstensi dan fleksi pada } \\
\text { sendi siku, ekstensi dan fleksi pergelangan tangan dan } \\
\text { jari-jari, abduksi dan adduksi jari, abduksi dan ekstensi } \\
\text { ibu jari. } \\
\text { - Untuk mengevaluasi kelemahan yang ringan dapat } \\
\text { dilakukan pemeriksaan pronator drift, forearm rolling } \\
\text { test, dan fine finger movement test. } \\
\text { - Evaluasi fungsi motorik halus dapat dilakukan dengan } \\
\text { menginstruksikan pasien untuk memasang dan } \\
\text { membuka kancing baju, mengepalkan tangan, } \\
\text { memasang klip kertas, menulis, membuat tanda "o" } \\
\text { dengan ibu jari dan jari telunjuk, atau menjentikan jari. }\end{array}$ & \\
\hline $\begin{array}{l}\text { Ekstremitas } \\
\text { Inferior }\end{array}$ & $\begin{array}{l}\text { Inspeksi: } \\
\text { - Perhatikan simetrisitas posisi anatomis dan saat } \\
\text { ekstremitas bergerak, atrofi otot, fasikulasi postur dan } \\
\text { gerakan involunter. } \\
\text { Pemeriksaan obyektif: } \\
\text { - Instruksikan pasien untuk mengayunkan tungkainya saat } \\
\text { duduk di tepi kursi atau tempat tidur guna memeriksa } \\
\text { tonus. } \\
\text { - Instruksikan pasien untuk melakukan gerakan melawan } \\
\text { gravitasi berupa fleksi dan ekstensi pada sendi panggul, } \\
\text { abduksi pada sendi panggul, fleksi pada lutut, } \\
\text { dorsofleksi dan plantarfleksi, abduksi dan aduksi kaki, } \\
\text { fleksi jari-jari kaki, abduksi jari-jari kaki. } \\
\text { - Instruksikan pasien untuk berdiri dengan lengan } \\
\text { disilangkan di badan, berdiri dengan satu kaki } \\
\text { bergantian, berdiri dengan tumit (mengevaluasi } \\
\text { kekuatan dorsofleksi), berdiri dengan berjinjit } \\
\text { (mengevaluasi kekuatan plantarfleksi). }\end{array}$ & \\
\hline
\end{tabular}


Tabel 3. Formulir Pemeriksaan Neurologi Virtual (Lanjutan)

Pemeriksaan

Prosedur

Interpretasi

6. Koordinasi dan Fungsi Serebelum

Ekstremitas Inspeksi untuk evaluasi gerakan involunter seperti tremor

superior - Instruksikan pasien untuk melakukan tes telunjukhidung untuk mengevaluasi dismetri.

- Instruksikan pasien untuk melakukan gerakan alternan cepat untuk mengevaluasi bradikinesia yang meliputi finger taps, membuka dan mengepalkan tangan, pronasi dan supinasi tangan dengan cepat.

Badan Inspeksi untuk mengevaluasi adanya ataksia trunkal

- Instruksikan pasien untuk bangun dari tidur ke posisi duduk dengan lengan disilangkan di depan dada untuk mengevaluasi asinergia serebelar.

Ekstremitas Inspeksi untuk evaluasi gerakan involunter seperti tremor

Inferior - Instruksikan pasien untuk melakukan tes tumit-lutut-ibu jari kaki.

- Instruksikan pasien untuk melakukan gerakan alternan cepat yang meliputi gerakan mengayuh dengan kedua tungkai saat tidur terlentang dan foot tapping.

Gaya Jalan Inspeksi postur pasien saat berdiri tegak dengan kedua kaki rapat

- Instruksikan pasien untuk berjalan dua arah (membelakangi dan menghadap kamera) minimal lima langkah untuk masing-masing arah.

- Instruksikan pasien untuk melakukan berjalan tandem.

Evaluasi kelainan gaya berjalan yang dapat berupa wide base gait, waddling gait, petit march, Trendelenburg gait, dan hemiparetic gait.

\section{Gerakan Involunter}

Ekstremitas Inspeksi untuk mengevaluasi gerakan involunter saat superior pasien dalam posisi istirahat

dan inferior

- Instruksikan pasien untuk menggerakan lengan dan

Korea/ atetosis/ tungkainya melawan gravitasi untuk mengevaluasi kualitas dan kuantitas gerakan involunter selama bergerak.

Evaluasi apakah amplitudo dan frekuensi gerakan involunter dipengaruhi oleh distraksi selama melakukan wawancara atau pemeriksaan lainnya.

8. Parkinson Inspeksi

Kinetik

- Mimik wajah

Bradikinesia

- Postural

- Gaya jalan

Pemeriksaan:

Mengancing baju

Tonus Instruksikan pasien untuk:

- Menulis

Membuka/ menutup jari tangan

Gerakan Inspeksi: tremor

Resting/ pill rolling involunter 
Tabel 3. Formulir Pemeriksaan Neurologi Virtual (Lanjutan)

\begin{tabular}{|c|c|c|}
\hline Pemeriksaan & Prosedur & Interpretasi \\
\hline \multicolumn{3}{|l|}{ 9. Sensorik } \\
\hline $\begin{array}{l}\text { Ekstremitas } \\
\text { superior, } \\
\text { badan, dan } \\
\text { ekstremitas }\end{array}$ & $\begin{array}{l}\text { Pemeriksaan subyektif: } \\
\text { - Sesuai dengan keluhan subyektif pasien kemudian } \\
\text { pasien diminta untuk menggambarkan area dikulit } \\
\text { yang dikeluhkan mengalami gangguan sensiblitas. }\end{array}$ & $\begin{array}{l}\text { Gangguan sensorik } \\
\text { perifer/ sentral }\end{array}$ \\
\hline \multirow[t]{2}{*}{ inferior } & $\begin{array}{l}\text { Pemeriksaan obyektif: } \\
\text { - Pendamping diinstruksikan untuk melakukan } \\
\text { pemeriksaan dengan menggunakan kapas atau tisu, } \\
\text { kantong es atau sendok dingin dan tusuk gigi. }\end{array}$ & \\
\hline & $\begin{array}{l}\text { Pemeriksaan proprioseptif dapat dilakukan dengan } \\
\text { bantuan pendamping. }\end{array}$ & \\
\hline Pemeriksaan & - Pemeriksaan dilakukan apabila ada keluhan spesifik. & \\
\hline Stimulasi saraf & $\begin{array}{l}\text { Pasien dengan dibantu oleh pendamping diinstruksikan } \\
\text { untuk melakukan tes tinel/ phalen/ prayer, tes Lermitte } \\
\text { dan straight leg raising test. }\end{array}$ & \\
\hline
\end{tabular}

Pemeriksaan Motorik, Koordinasi, Gaya Jalan, dan Gerakan Involunter secara Virtual

Dokter pemeriksa harus mempertimbangkan tingkat pendidikan pasien dan anggota keluarga yang berperan selaku pendamping sebelum memutuskan pendamping ikut berperan aktif saat PNV. Diperlukan instruksi yang lebih rinci bila akan dikerjakan oleh pendamping dan dokter harus berhati-hati dalam menginterpretasinya dengan menggabungkan temuan klinis lainnya. ${ }^{20}$

Ada keterbatasan untuk mengerjakan seluruh pemeriksaan motorik. Idealnya pemeriksaan meliputi penilaian kekuatan otot berdasarkan the Medical Research Council scale for muscle strength dengan skala $0-5$, pemeriksaan tonus otot, dan evaluasi terhadap refleks tendon. Pemeriksaan kekuatan otot dilakukan secara sistematis dari proksimal ke distal pada ekstermitas atas dan bawah. ${ }^{7}$ Pemeriksaan motorik pada PNV terbatas untuk mengevaluasi atrofi, kemampuan melawan gravitasi dan tahanan yang diberikan oleh pendamping, penilaian fungsi duduk, berdiri, dan berjalan. Kelemahan ringan ekstremitas superior dapat diperiksa dengan pemeriksaan pronator drift, forearm rolling test, dan tapping thumb. Kelemahan pada ekstremitas inferior dapat diperiksa dengan meminta pasien berdiri dengan kedua tangan bersilang di dada, jongkok-bangun, berdiri/ berjalan dengan tumit dan jari-jari kaki. ${ }^{3,6,19}$ Kondisi tonus otot masih dapat dievaluasi melalui PNV dengan meminta pasien menggerakan lengan dan tungkainya (shaking hand/arms, dan shaking leg). ${ }^{20}$ Pemeriksaan refleks pada PNV masih mungkin dilakukan dengan bantuan pendamping yang mampu memahami intruksi yang diberikan pemeriksa, seperti pada pemeriksaan refleks Babinski. ${ }^{19,20}$

Pemeriksan koordinasi dan gaya jalan dapat diperiksa dengan berjalan tandem dan tes Romberg. Pemeriksaan ini memerlukan pendamping yang berada di dekat pasien atau pasien berada didekat dinding/benda yang stabil yang akan digunakan untuk menumpu dan berpegangan bila pasien kehilangan keseimbangan. ${ }^{20}$

Pemeriksaan motorik spesifik pada penyakit parkinson dapat dilakukan dengan berpedoman pada Unified Parkinson's Disease Rating Scale (UPDRS). ${ }^{3,22}$ Bradikinesia, tremor dan gerakan involunter dapat diobservasi melalui video. ${ }^{22}$

\section{Pemeriksaan Sensorik secara Virtual}

Pemeriksaan sensorik dibagi menjadi sistem anterolateral (nyeri, suhu, raba dan tekan) dan sistem posterior (vibrasi dan posisi) yang bersifat subyektif murni. bergantung pada akurasi pemeriksa dan kerjasama pasien. ${ }^{7}$ Pemeriksaan sensorik pada PNV memiliki banyak keterbatasan. Metode pemeriksaan ini membutuhkan keahlian pemeriksa secara langsung untuk mengurangi keluhan pasien yang terlalu subjektif. Untuk keperluan penapisan adanya gangguan sensoris, pendamping dapat diinstruksikan untuk melakukan pemeriksaan sensorik menggunakan kapas atau tisu, kantong es atau sendok dingin, dan tusuk gigi. ${ }^{19,20}$ Pemeriksaan ataksia sensorik dilakukan dengan meminta pasien untuk menyentuh hidung dan jarinya dengan mata tertutup menggunakan telunjuk kiri dan kanan secara bergantian. ${ }^{6}$ 
Penulis mempersiapkan video demonstrasi guna membantu klinisi, khususnya neurolog, untuk melakukan PNV di tempat tugasnya. Video demonstrasi dapat diakses melalui laman website www.rs.unud.ac.id atau www.perdossidenpasar.org. Video tersebut telah didaftarkan dan memiliki nomor Hak atas Kekayaan Intelektual.

\section{Simpulan}

Pemeriksaan neurologi di era COVID-19 masih memungkinkan dilaksanakan secara virtual dengan

\section{Daftar Rujukan}

1. World Health Organization. Infection prevention and control during health care when novel coronavirus (nCoV) infection is suspected. 2020. https://www.who.int/publications/i/item/10665331495

2. World Health Organization. Rational use of personal protective equipment for coronavirus disease (COVID-19) and considerations during severe shortages. 2020.

https://apps.who.int/iris/rest/bitstreams/12743 40/retrieve

3. World Health Organization. Coronavirus disease (COVID-19) Pandemic. 2020 https://www.who.int/emergencies/diseases/nov el-coronavirus-20192020).

4. Moazzami B, Razavi-Khorasani N, Dooghaie Moghadam A, Farokhi E, Rezaei N. COVID-19 and telemedicine: Immediate action required for maintaining healthcare providers well-being. J Clin Virol 2020; 126: 104345.

5. Roy B, Nowak RJ, Roda R, et al. Teleneurology during the COVID-19 pandemic: A step forward in modernizing medical care. J Neurol Sci 2020; 414: 116930.

6. Al Hussona $M$, Maher $M$, Chan $D$, et al. The Virtual Neurologic Exam: Instructional videos and guidance for the COVID-19 era. Can J Neurol Sci 2020: 1-22.

7. Corbett JJC, J. The Neurologic Examination. In: Haines DEM, G.A., ed. Fundamental Neuroscience for Basic and Clinical Applications. Fifth ed. Philadelphia: Elsevier; 2018: 480-93.

8. Campbell WBRJ. De Jong's The Neurologic Examination. Eighth ed. Philadelphia: Lippincott Williams \& Wilkins; 2020.

9. Talley NJ, O'Connor, Simon. The neurological history - Talley \& O'Connor's Clinical Examination. In: Talley NJ, O'Connor, Simon, ed. Talley \& O'Connor's Clinical Examination. Eighth ed. Australia: Elsevier; 2018: 489-99. persiapan yang memadai serta kerjasama yang baik antara dokter pemeriksa dan pasien. Keterbatasan hasil PNV dan interpretasinya harus dijelaskan pada awal pemeriksaan. Pelatihan pelaksanaan PNV bagi dokter spesialis neurologi sangat diperlukan.

\section{Konflik Kepentingan}

Tidak ada konflik kepentingan.

10. Ansary AM, Martinez JN, Scott JD. The virtual physical exam in the 21st century. I Telemed Telecare 2019: 1357633X19878330.

11. Wechsler LR. Advantages and limitations of teleneurology. JAMA Neurol 2015; 72(3): 349-54.

12. Perhimpunan Dokter Spesialis Saraf Indonesia. Panduan Konsultasi Daring PERDOSSI. In: PERDOSSI, editor. Jakarta; 2020.

13. Dewan Teknologi Informasi dan Komunikasi W. Strategi Telemedicine Hadapi COVID-19. Wantiknas. 2020.

14. Davenport RM, Hadi;. The nervous system. In: Innes JAD, Anna R; Fairhurst, Karen, ed. Macleod's Clinical Examination. UK: Elsevier; 2018: 119-50.

15. Menteri Kesehatan. Peraturan Menteri Kesehatan Republik Indonesia No 20 Tahun 2019 tentang Penyelenggara Pelayanan Telemedicine antar Fasilitas Pelayanan Kesehatan. In: Kementerian Kesehatan RI, editor. Jakarta; 2019.

16. Menteri Kesehatan. Surat Edaran Nomor HK.02.01/MENKES/303/2020 tentang Penyelenggaraan Pelayanan Kesehatan melalui Pemanfaatan Teknologi Informasi dan Komunikasi dalam Rangka Pencegahan Penyebaran Corona Virus Disease 2019 (COVID19). In: Kementrian Kesehatan RI, editor. Jakarta; 2020.

17. Wechsler LR, Tsao JW, Levine SR, et al. Teleneurology applications: Report of the Telemedicine Work Group of the American Academy of Neurology. Neurology 2013; 80(7): 670-6.

18. Misra UK, Kalita J, Mishra SK, Yadav RK. Telemedicine in neurology: underutilized potential. Neurol India 2005; 53(1): 27-31.

19. American Academy of Neurology. Telemedicine and COVID-19 Implementation Guide. American Academy of Neurology 2020. https://www.aan.com/siteassets/homepage/tools-and-resources/practicing-neurologist-administrators/telemedicine-and-remotecare/20-telemedicine-and-covid19-v103.pdf 
20. Grossman SN, Han SC, Balcer LJ, et al. Rapid implementation of virtual neurology in response to the COVID-19 pandemic. Neurology 2020; 94(24): 1077-87. 